\title{
Phyllody of faba bean in the Sudan. I. Progress of symptom expression, host range and transmis- sion to Catharanthus roseus through dodder
}

Gazim Abdalla DAFALLA (*) \& Marie-Thérèse COUSIN

I.N.R.A., Station de Pathologie végétale, Route de Saint-Cyr, F 78000 Versailles

Symptom development of faba bean phyllody was followed in a local susceptible cultivar, Hudeiba 72 , graft-inoculated from naturally diseased plants collected in the Gezira. The disease was characterized by a series of floral abnormalities including virescence, phyllody and proliferation of sprouts together with other growth abnormalities, such as loss of apical dominance, vivipary and cnhanced vegetative growth. All three Sudanese cultivars tested in the glasshouse were highly vulnerable to the pathogen while the European cultivar tested showed mild symptoms and slow development of disease, sometimes partial recovery. Symptom expression in faba bean plants was highly influenced by temperaturc. Plants grown at $15-18{ }^{\circ} \mathrm{C}$ produced no or occasionally mild symptoms after prolonged incubation periods, whereas at $20-22{ }^{\circ} \mathrm{C}$ characteristic symptoms appeared. French bean, dolichos bean, pigeon pea and lucerne were sensitive to infection after grafting from faba bean and reacted with yellowing symptoms. The disease agent was also transmitted through dodder (Cuscuta subinclusa) to the differential host Catharanthus roseus. Three distinct stages of symptom development were observed in $C$. roseus and each was characterized by a particular symptom type. These symptoms were identical to those induced by the MLOs of Crotalaria saltiana phyllody described in the same region.

Additional key words : Vivipary, witches broom.

RESUMÉ

Phyllodie de la féverole au Soudan. I. Evolution des symptômes, gamme d'hôtes et transmission par cuscute (Cuscuta subinclusa) à Catharanthus roseus.

L'évolution des symptômes de la phyllodie de la féverole a été suivie sur une variété sensible : "Hudeiba 72 ", greffée à partir de plantes malades provenant de Gezira. La maladie est caractérisée par une série d'anomalies de l'appareil reproducteur: virescence, phyllodie, prolifération des fleurs et viviparité des gousses ainsi que des anomalies de l'appareil végétatif, telles que la perte de la dominance apicale et la prolifération. Les trois variétés soudanaises testées par greffage se sont montrées sensibles à l'infection alors que la variété européenne : "Ascott " était peu affectée par la maladie. L'expression des symptômes chez la féverole est largement influencée par la température. A des températures de 15 à $18{ }^{\circ} \mathrm{C}$ les plantes ne présentent aucun symptôme ou parfois des symptômes très légers après une longue période d'incubation, alors qu'à des températures de 20 à $22^{\circ} \mathrm{C}$ des symptômes caractéristiques apparaissent. Quatre espèces de légumineuses : le haricot, le dolic, le pois d'Angole et la luzerne sont sensibles à l'infection et ont montré des symptômes de jaunissement du feuillage. L'agent pathogène a été transmis par cuscute (Cuscuta subinclusa) à un hôte différentiel : Catharanthus roseus. Trois stades de la maladie, caractérisés par des symptômes particuliers, ont été mis en évidence. L'ensemble de ces symptômes observés au cours de ces différents stades est identique à ceux de la phyllodie de Crotalaria saltiana prélevée dans la même région du Soudan.

Mots clés additionnels : Viviparité, prolifération.

\section{INTRODUCTION}

Faba bean (Vicia faba L.), is the major edible grain legume cultivated and consumed throughout the Nile Valley of Egypt and Sudan. Its cultivation in the Sudan

*Permanent adress : Faculty of Agric. Sci., Univ. Gezira, Wad Medani, Sudan. is mainly in the Northern region (latitude $16^{\circ} \mathrm{N}$ ), although further southward expansion is envisaged to satisfy increasing market demands. Several fungal and viral diseases were reported to inflict great losses of faba bean crops in the Sudan (Hussein \& Freigoun, 1978 ; Hussein, 1979). Phyllody disease had been sporadic during the 1950s (Nour, 1962) and 1970s (HuSSEIN, 1976). However, in recent years $(1982 / 83)$ up to $20 \%$ infection was recorded in some crops in the Gezira 
(JONES et al., 1984). The impact of the disease thus seems to increase and losses can be considerable since infected plants do not produce seeds.

The disease was first reported by Nour (1962) who succeeded in transmitting the pathogen through grafting but not by sap inoculation or with the leafhopper Empoasca lybica Berg. HussEIN (1976, 1978) described the disease on several varieties grown in the northern part of Sudan and reported that disease incidence was highest in early sown crops. Additional evidence of MLO etiology was recently provided by JONES et al. (1984) and DAFAlla \& Cousin (1986) working with diseased plants from Sudan. The association of MLOs with a disease in faba bean was first reported by Cousin et al. (1970) from Morocco but there is no evidence concerning the relationship of this disease with faba bean phyllody in the Sudan.

Since the disease appears to be a potential threat to the cultivation of faba bean, especially in central Sudan, further study of the disease and of its causal MLO seemed justified. In this part of our study, some ecological aspects of the disease were investigated with special regard to host reactions and the effect of temperature on symptom expression.

\section{MATERIALS AND METHODS}

\section{A. Origin of diseased materials}

Brief surveys were made on faba bean crops grown at the experimental farm of the Gezira Research Station, Wad Medani, during the winter season of $1984 / 85$. Diseased plants of cv. BF $2 / 2$ were collected from several experimental plots, sealed in polythene bags and shipped to Versailles. For symptomatological and hostrange studies, one of the isolates was maintained and propagated by graft-inoculation onto faba bean. This isolate was later transferred to $C$.roseus for long-term maintainance.

\section{B. Graft transmission to faba bean}

Phylloid flowers, usually with elongated pedicels, were inserted in clefts prepared in the axils of the first expanded leaf on 2-3 week-old faba bean plants, tied with parafilm and covered with small polythene bags to reduce transpiration. They were then placed in a glasshouse at a temperature of $22-26^{\circ} \mathrm{C}$. Successful grafts were kept under frequent observation for several months.

\section{Effect of temperature on symptoms expression}

During the varietal tests, some differences in symptom expression were observed between plants grown at different temperatures. A preliminary test was made to study such temperature effects. Plants of $\mathrm{cv}$. BF 2/2 were grafted as described above and placed, in two groups each of 10 test plants and 10 controls, in two different glasshouses at temperatures of $15-18^{\circ} \mathrm{C}$ and $20-22^{\circ} \mathrm{C}$.

\section{Dodder transmission to Catharanthus roseus}

Plants of C. roseus (periwinkle) were prepared from a clone of known reactions to as many as $12 \mathrm{MLO}$ diseases. Seedling of dodder (Cuscuta subinclusa) was allowed to parasitize diseased faba bean plants for about 5 weeks. Established dodder strands were then led onto healthy plants of $C$.roseus while gradually disconnected from faba bean plants. Dodder remnants were removed from periwinkles four weeks later and test plants were kept clean in a warm glasshouse $\left(25-30{ }^{\circ} \mathrm{C}\right)$. Periwinkle plants parasitized by dodder strands reared on healthy faba bean plants were prepared to serve as controls.

\section{RESULTS}

\section{A. Symptom development}

Symptom development in graft-inoculated plants of faba-bean, Hudeiba 72, was recorded at 2-day intervals during the first 6 weeks after grafting and then at 2-4 day intervals for as long as 6 months. During this period a succession of symptoms was observed and the eventual syndrome involved the entire plant. The first symptoms appeared within two weeks after grafting and consisted of mild yellowing, vein clearing and slight inward folding of newly formed leaves in the apical region of the plant. In such plants, flower symptoms started to show-up one week later. Young plants that developed systemic infection during flower bud initiation invariably produced phylloid flowers (fig. 1) whereas virescent, phylloid and healthy flowers were observed in older plants. Some flower buds in late infected plants were found to produce pods with fertile or aborted seeds. In these pods vivipary was frequently observed. The hypocotyls of developing seedlings ruptured through the walls of pods while their roots developed inside the pod (fig. 2).

Phylloid flowers from severely affected faba bean plants showed excessive proliferation of receptacle (fig. 3). Primary proliferation was followed by secondary and tertiary proliferations which contributed to witches' broom symptoms. New virescent flowers continued to arise for as long as five months.

Excessive sprouting of buds in vegetative basal parts of the plant started about 6 weeks after grafting and coincided with complete cessation of apical growth. In advanced disease stages bud proliferation became excessive while the main stem became yellow and finally desiccated (fig. 4). These visible above-ground symptoms were also accompanied by characteristic modifications of the root system. They consisted of root proliferation and excessive necrosis. Nodulation was highly affected and diseased plants produced small necrotic and deformed nodules (fig. 5). 


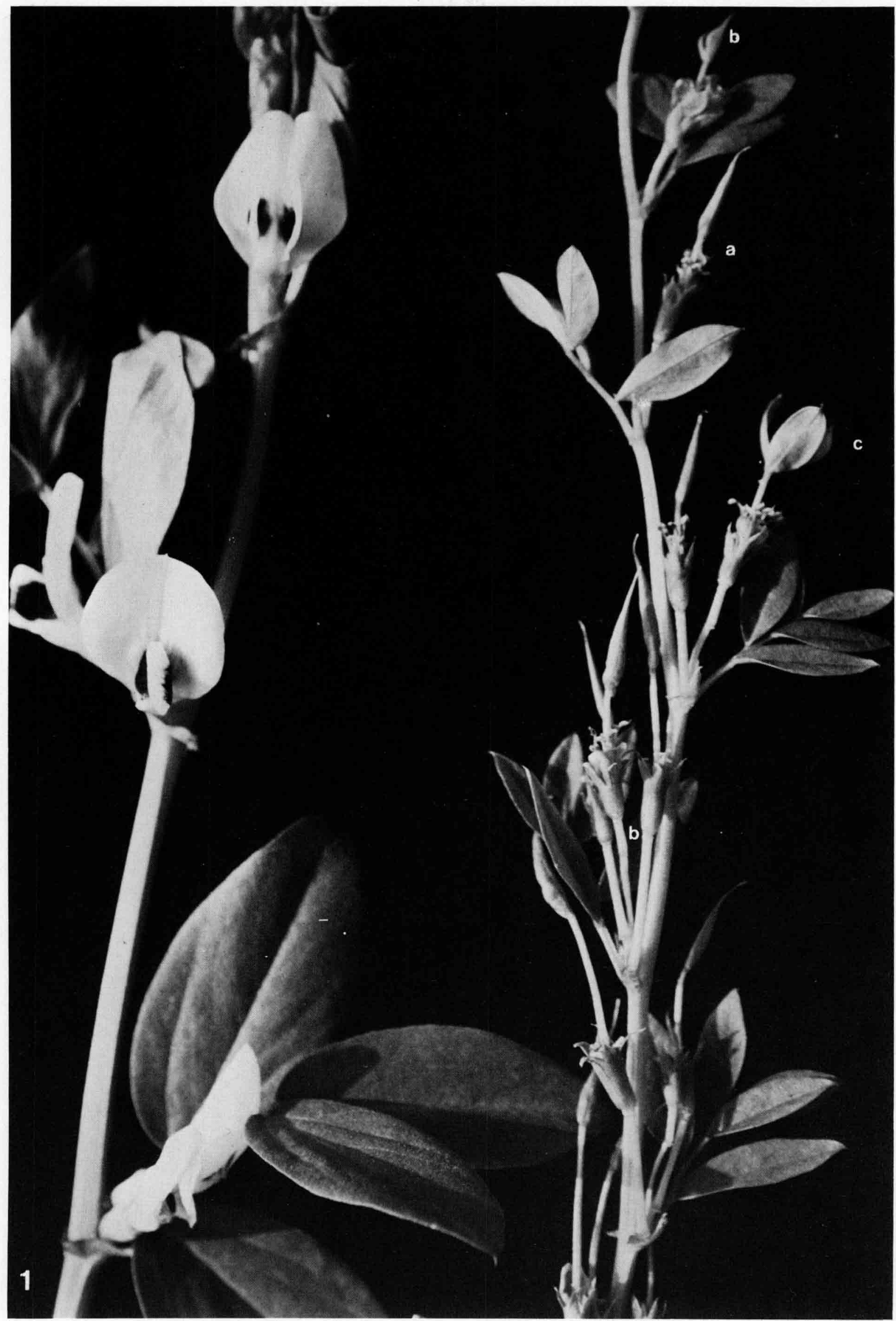

I.igure 1

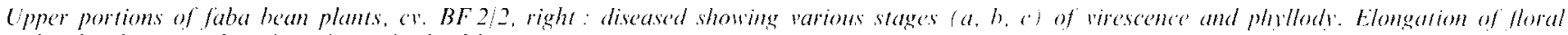
pedtuncle's, hipertrophly of pistils. Lefi: healthy.

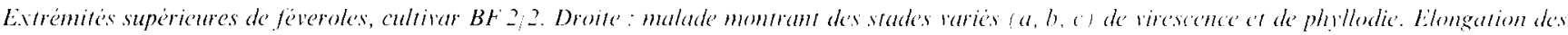

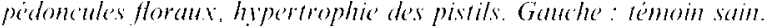



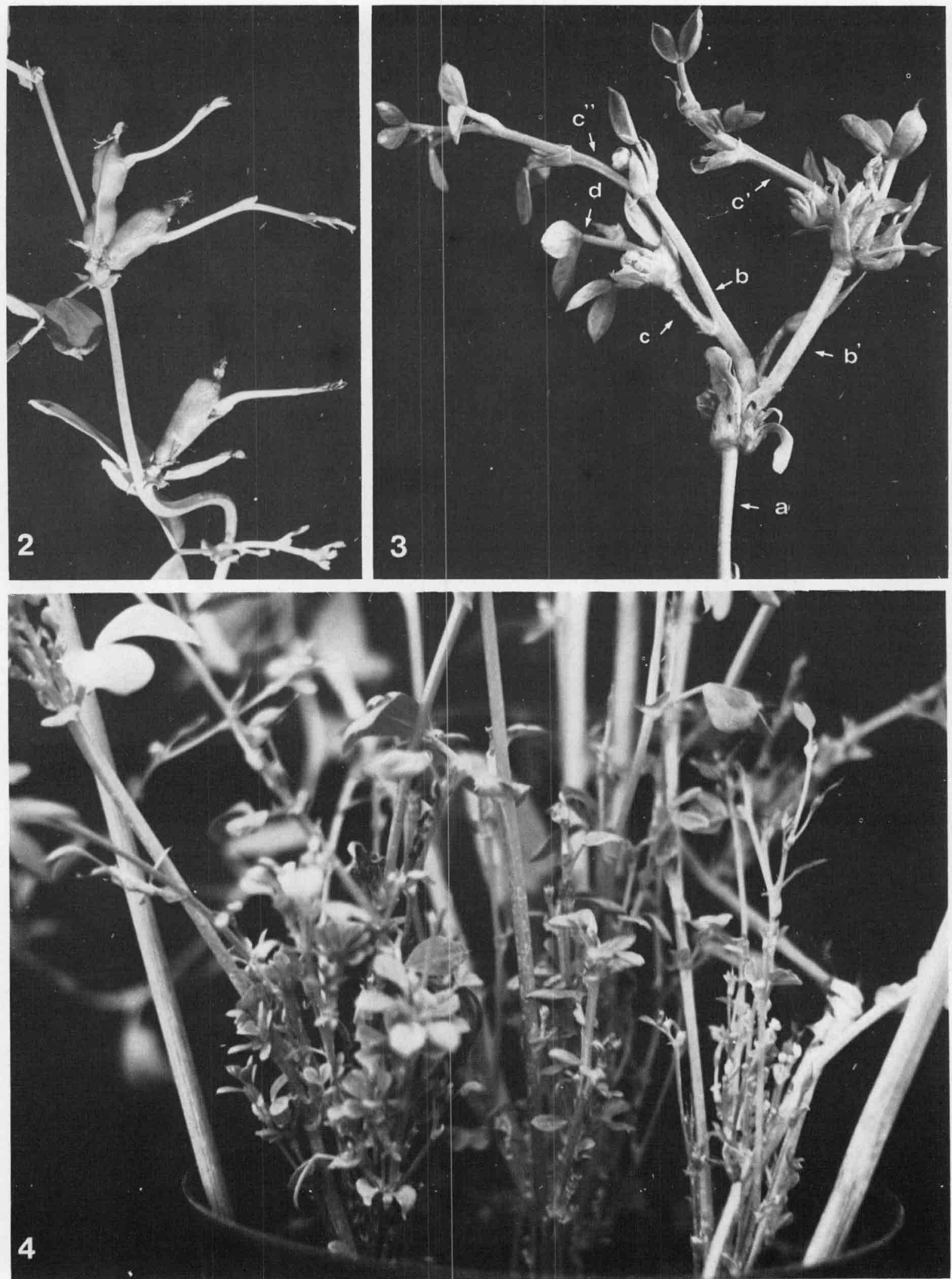

Figure 2

Seed germination inside immature pods: vivipary (diseased plant).

Germination des graines à l'intérieur de gousses immatures: viviparité (plante malade).

Figure 3

Phylloid flower (a) from severely affected faba bean plant showing proliferation of receptacle : primary proliferation into vegetatives branches $\left(b, b^{\prime}\right)$ which further undergo secondary $\left(c, c^{\prime}, c^{\prime \prime}\right)$, tertiary $(d)$, etc... proifferations contributing to witches' broom simptoms.

Fleur phyllö̈de (a) sur un plant de féverole très malade montrant une prolifération du réceptacle : prolifération primaire en pousses végétatives $\left(b, b^{\prime}\right)$ qui évoluent en proliférations secondaires, $\left(c, c^{\prime}, c^{\prime \prime}\right)$, tertiaire $(d)$, etc..., contribuant au développement des sumptômes de "Witches'broom".

Figure 4

Proliferation of axillary buds in the basal part of diseased plants : witches' broom.

Prolifération des bourgeons axillaires de la partie hasale des plantes malades : balais de sorcière (witches' broom). 

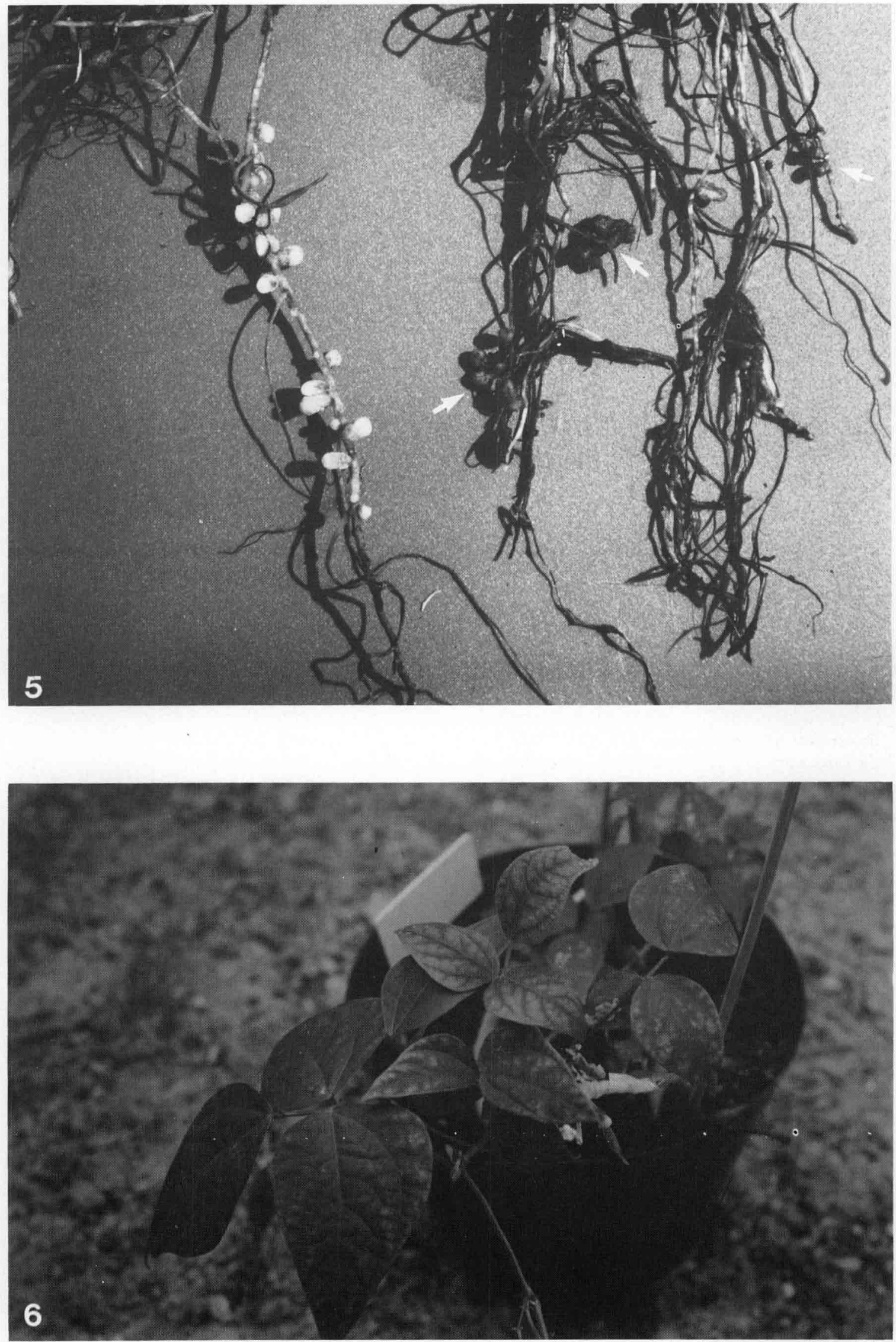

Figure 5

Root symptoms of faba beail phyllody. Right : diseased roots. Note necrosis and deformed modules. Left : healthy.

Symptomes racinaires de la phyllodie de la féverole. Droite: racines infectées, noter les nécroses et la déformation des nodules. Gauche : Témoin sain.

Figure 6

French bean (Phaseolus vulgaris) graft-inoculated with faha be an phyllody. Note the interveinal yellowing.

Haricot (Phaseolus vulgaris) ino'ule par greffage à partir de féverole atteinte de phyllodie. Noter le jannissoment internervire. 


\section{B. Faba bean varietal reaction at temperatures of 20 - $22{ }^{\circ} \mathrm{C}$}

Symptom development was followed in the glasshouse using three cultivars widely grown in the Sudan (BF 2/2, Hudeiba 72 and Selaim) and the European cultivar Ascott. In the four faba bean cultivars three stages of disease development could be distinguished (table 1): initial foliar symptoms, first floral symptoms, and witches' broom growth. Disease progress was recorded accordingly. All cultivars were sensitive to attack. However, the European cultivar Ascott suffered considerably less than the three Sudanese cultivars. While the latter showed foliar symptoms within 22 to 29 days, no such symptoms were observed in any of the 11 plants of cultivar Ascott (table 1). Floral symptoms started 43 days after grafting in comparison to about 28 in the Sudanese varieties. In addition, no witches' broom development occurred in Ascott and affected plants of this variety frequently showed partial recovery and produced fertile flowers. Differences within Sudanese cultivars were slight (table 2).

\section{Effect of temperature on symptom expression}

Sudanese cultivars of faba bean plants grown at temperatures of $20-22{ }^{\circ} \mathrm{C}$ invariably showed virescence within about 28 days following grafting. Subsequent disease development normally continued as described earlier. Conversely, at temperatures between $15-18^{\circ} \mathrm{C}$, only 5 transmissions out of 10 successful grafts were obtained and floral symptoms started 42 days after grafting. In addition, partial infection was common among these plants and most of them produced nume- rous fertile flowers. Plant growth was highly favoured at temperatures of $15-18^{\circ} \mathrm{C}$ with increased growth rate and larger plant size than at $20-22^{\circ} \mathrm{C}$.

\section{Host range}

Four legume species commonly cultivated in faba bean areas were tested by graft inoculation, viz. local Sudanese varieties of Phaseolus vulgaris L. (french bean), Cajanus cajan L. (pigeon pea), Lablab vulgaris Savi. (dolichos bean) and Medicago sativa L. (lucerne). Characteristic foliar symptoms were observed in french bean, pigeon pea, dolichos bean and lucerne, grafted from diseased faba bean. All four plant species reacted in a similar manner with symptoms consisting of stunted growth, reduction of leaf size and characteristic interveinal yellowing. Cessation of flower bud initiation was observed during early stages of disease, but normal flowering was later observed in lateral shoots (fig. 6).

\section{E. Transmission to $C$. roseus}

Transmission of faba bean phyllody was successful through dodder to healthy plants of $C$. roseus. Disease development was systematically followed in young plants grafted with portions from dodder-inoculated plants. Three distinct stages of disease development were recognized and each of them seemed to be of particular interest when compared to reactions to other MLO diseases induced in this host (table 2).

Initial symptoms were common to most diseases and consisted of faint foliar yellowing, undulation of leafmargins and twisting of midribs. They were mainly characterized by various degrees of colour breaking and

TABLE 1

Symptom development in three Sudanese and one European faba bean cultivars, graft-inoculated with faba bean phyllody (temperature 20 -22 ${ }^{\circ} \mathrm{C}$ ). Evolution des symptômes sur trois cultivars soudanais é un cultivar curopéen dé féverole, inoculés par greffage à partir de féverole atteinte de la phyllodie et cultivés à des températures de 20 à $22^{\circ} \mathrm{C}$.

\begin{tabular}{|c|c|c|c|c|c|c|}
\hline \multirow[b]{2}{*}{$\begin{array}{l}\text { Faba bean } \\
\text { cultivars }\end{array}$} & \multicolumn{2}{|c|}{$\begin{array}{c}\text { Initial } \\
\text { symptoms }\end{array}$} & \multicolumn{2}{|c|}{$\begin{array}{l}\text { First floral } \\
\text { symptoms }\end{array}$} & \multicolumn{2}{|c|}{$\begin{array}{c}\text { Witches' broom } \\
\text { growth }\end{array}$} \\
\hline & $\begin{array}{l}\text { Mean time } \\
\text { in days }\end{array}$ & Number (l) & $\begin{array}{l}\text { Mean time } \\
\text { in days }\end{array}$ & Number (1) & $\begin{array}{l}\text { Mean time } \\
\text { in days }\end{array}$ & Number (1) \\
\hline $\begin{array}{l}\text { Sudan origin } \\
\text { BF } 2 / 2\end{array}$ & 22 & $16 / 16$ & 26 & $14 / 16$ & 38 & $15 / 16$ \\
\hline Hudeiba 72 & 25 & $12 / 12$ & 27 & $12 / 12$ & 51 & $10 / 12$ \\
\hline Selaim & 29 & $16 / 16$ & 31 & $16 / 16$ & 48 & $14 / 16$ \\
\hline $\begin{array}{l}\text { European origin } \\
\text { Ascott }\end{array}$ & - & $0 / 11$ & 43 & $9 / 11$ & - & $0 / 11$ \\
\hline
\end{tabular}

(1) Number of plants showing symptoms over total number of sucessilui gralts. 

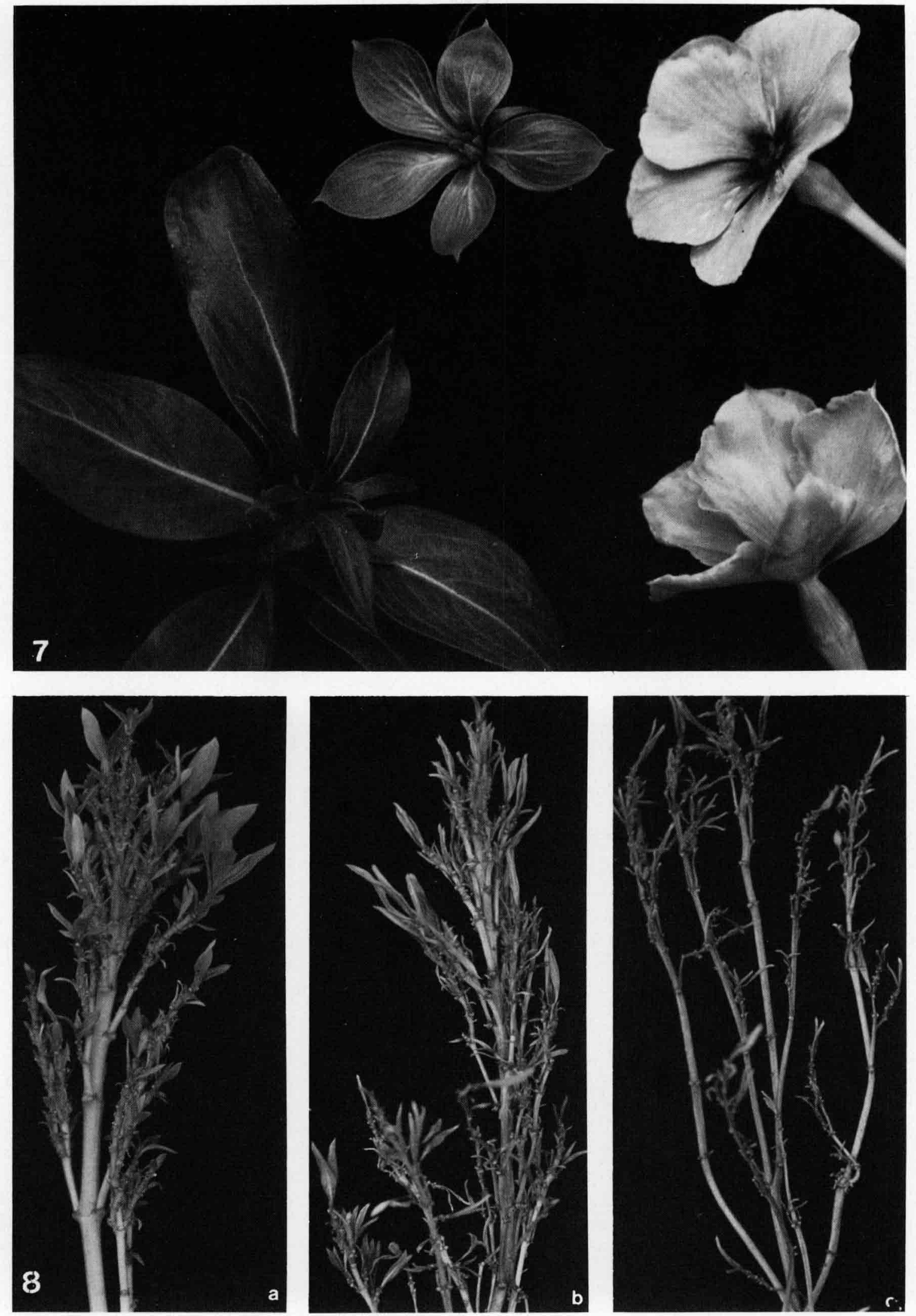

Figure 7

Successive stages of floral transformation on $\mathrm{C}$. roseus dodder inoculated with faha bean phyllody : greening of petals, phyllody and floral transformation into leafi structures.

Stages progressifs de transformation florale che C. roseus inocule par cuscute ave la phyllodie de la feverole : verdissement des pétales, phyllodie st transformation des pices florales en structures foliaceses.

Figure 8

Late stage of disease in $\mathrm{C}$. roseus :

(a) Prolifération of axillary buds, reduction of leaf sizes, vellowing and shedding of leaves.

(b) Gradual drying of branches and leaves

(c) Complete drying and eventual death of branch.
Stades arancés de la maladie sur C. roseus:

(a) Prolifération des hourgeons avillaires, réduction de la laille. jaunisise et chute des fenilles.

(b) Dessechement progressif des fenilles et des rameax.

(c) Dessechement complet et mort éventuelle des pousses. 
TABLE 2

Comparisen of symptom types in Catharanthus roseus, dedder inoculated with faba bean phyllody and Crotalaria saltiana phyllody from Sudan, with these inderced by some selecied $M L O$ discesses fiom Sudan and France.

Comparaison des sympromes ohservés sur C. roseus inoculé par cuscute à partir de féverole et de Crotalaria atteints de phyllodie an Sudan aree ceux

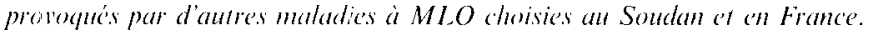

\begin{tabular}{|c|c|c|c|}
\hline \multirow{4}{*}{$\begin{array}{l}\text { MLO diseases } \\
\text { Faba bean phyllody } \\
\text { (FBP) (Sudan) } \\
\text { and } \\
\text { Crotalaria saltiana } \\
\text { phyllody (Sudan) }\end{array}$} & \multicolumn{3}{|c|}{ Stages of symptom development } \\
\hline & $\mathrm{I}$ & II & III \\
\hline & $\begin{array}{c}\text { Gradual greening of } \\
\text { petals }\end{array}$ & $\begin{array}{l}\text { Phyllody. No further } \\
\text { proliferation }\end{array}$ & $\begin{array}{c}\text { Witches' broom of vegetative origin } \\
\text { Production of small yellowing leaves } \\
\text { Axillary bud proliferation } \\
\text { Dieback of branches }\end{array}$ \\
\hline & $\begin{array}{l}\text { Light yellowing of the } \\
\text { leaves }\end{array}$ & $\begin{array}{l}\text { Succesive yellowing and } \\
\text { shedding of older leaves }\end{array}$ & \\
\hline Elm witches' broom* & Small flowers & No phyllody & $\mathrm{FBP}$ \\
\hline $\begin{array}{l}\text { Grassy shoot of Gladiohus } \\
\text { and French isolate of } \\
\text { Hydrangea viresecnce }\end{array}$ & FBP & $\begin{array}{l}\text { Flower proliferation } \\
\text { (mainly of pistils) }\end{array}$ & $\begin{array}{l}\text { Witches' broom } \\
\text { mainly of floral origin }\end{array}$ \\
\hline $\begin{array}{l}\text { Catharamthus roseus phyl- } \\
\text { lody (Sudan) } \\
\text { and Clover phyllody } \\
\text { (France) }\end{array}$ & FBP & $\begin{array}{l}\text { Phyllody "bunchy top" } \\
\text { symptoms }\end{array}$ & No Witches' broom \\
\hline $\begin{array}{l}\text { Stolbur of Solanacete } \\
\text { (France) }\end{array}$ & FBP & $\begin{array}{l}\text { Aborted floral parts } \\
\text { Hypertrophy of calyx }\end{array}$ & No Witches' broom \\
\hline
\end{tabular}

FBP : Symptoms similar to faba bean phyllody.

* MORVAN (Communication personnelle).

gradual greening of petals (virescence) (fig. 7). This stage was similar to that of most other MLO diseases (table 2) except those producing small flowers such as elm phloem necrosis.

Phyllody symptoms then developed. All floral parts changed into normal leaves at the end of this stage (fig. 7). This second stage was more characteristic than the first and despite the similarities with corresponding stages of other diseases it could easily be distinguished. For instance, it differed from stolbur in that no hypertrophy of calyx or reduction of internal floral parts was observed. It could also be differentiated from grassy shoot of Gladiolus and the french isolate of $\mathrm{Hyd}_{\mathrm{r}}$ rangea virescence in that it showed no proliferation of the pistil. Isolates of Catharanthus roseus phyllody from Sudan and clover phyllody from France showed similar phyllody symptoms, but the receptacles did not elongate preventing development of abnormal flowers into leafy branches, giving such plants a bunchy-top appearance.

While phyllody symptoms developed, successive yellowing and shedding of older leaves took place and when disease proceeded, all plant leaves were replaced by small yellowish ones. Witches' broom growth was prominent at this stage and characterized by excessive proliferation of axillary shoots (fig. 8a). This symptom stage, though seemingly similar to that in the case of Gladiolus grassy shoot and $H_{y}$ drangea virescence, could readily be distinguished by the origin of proliferation. Floral proliferation was the main source of witches' broom in the latter two diseases while vegetative proliferation of the entire plant was observed in faba bean and Crotalaria phyllody. Conversely, this stage was identical to that of elm phloem necrosis and these two diseases could only be differentiated during early stages (table 2). Subsequent yellowing and dieback of branches followed (fig. 8b, c). These successive stages observed for faba bean phyllody were identical to those reported in the case of Crotalaria saltiana phyllody from the same region in the Sudan (DAFALLA \& CoUSIN, unpublished).

\section{DISCUSSION}

Under field conditions, diseased faba bean plants were only recognizable at late stages of disease development, i.e. with phyllody and witches' broom. At this time, incidence is highest and no further spread seems to take place (HuSSEIN, 1978). Transmission tests to young faba bean plants performed during this study revealed that characteristic foliar symptoms preceeded phyllody and witches' broom. This would therefore permit earlier recognition of disease foci, and elimination of primary sources of infection. A point worth notice is that these early foliar symptoms could easily be confused with those of the very common bean leaf roll disease caused by a luteovirus, phloem-limited like MLOs (ICARDA. 1984 ; Bos, personal communication).

Faba bean phyllody seems to induce a series of growth disturbances as do other MLO diseases. This suggests abnormal hormonal activity (Bos, 1957, 1978). Such hormonal disturbances may also affect plant parts normally immune to MLO invasion. For instance, seed germination in immature pods formed before systemic infection as earlier described by Bos (1957) was now often observed in faba bean. This is not directly due to infection by MLOs because they cannot reach the embryos since there is no direct vascular connection between mother plant and embryos within seeds (ESAU, 1965) and MLOs do not pass through pollen grains (CoUSIN \& ABADIE, 1983). 
The progress of symptom expression studied in three Sudanese cultivars and one European faba bean variety revealed that they were all sensitive to infection. However, the European cultivar did not show initial leaf symptoms, virescence appeared late and plants sometimes partially recovered from disease. It may thus be of agronomic interest in having a considerable degree of resistance.

Temperature also seems to play a major role in symptom expression and subsequent disease development. Glasshouse temperatures of $15-18^{\circ} \mathrm{C}$ appear to favour plant growth while suppressing symptom development. At higher temperatures of $20-22{ }^{\circ} \mathrm{C}$, plants maintained vigorous growth though readily developing symptoms. Low temperature thus almost doubled the incubation period, reduced the proportion of successful transmissions and hindered the appearance of characteristic symptoms. This suggests that the effect of temperature is connected with the multiplication and translocation of MLOs in plant tissues.

Faba bean phyllody MLOs were transmitted to several leguminous crop species, including french bean, dolichos bean, pigeon pea and lucerne, usually cultivated in the cropping area of faba bean. They may play a role in the ecology of faba bean phyllody since some of them are treated as perennials and remain in the field for more than one season. Lucerne for instance, is an important fodder legume used throughout the year. MLOs could survive in this species during the dry summer period till the next faba bean growing season in winter. So a careful survey of the symptoms on these different host plants is now required. The results of dodder transmission to $C$. roseus have shown the similarity of the symptoms induced on this plant by faba bean and Crotalaria phyllody. These symptoms are different from the whole collection of MLO diseases maintained on C.roseus. So Crotalaria spp., widely distributed in the Sudan, is suspected to act as a means of survival of MLOs even over several years.

Different symptom types were observed to show up sequentially during disease development in C. roseus plants. Flower modifications during the two first stages of symptom development seem to indicate a period of active disease progress, followed by witches' broom growth usually associated with systemic infection of the entire plant. At a later decline stage, dieback of shoots becomes frequent while sprouting of lateral shoots continues in a perpetual manner. This sequential flower metamorphosis followed by witches' broom development observed in $C$. roseus is identical to that outlined by Bos $(1957,1978)$ regarding witches' broom phenomena in many diseases now ascribed to MLOs. In the case of faba bean further secondary flower proliferation occurred which may give leafy sprouts. In addition, virescent flower production continues as long as the plant is living even during later stages when these "flower-like" structures remain considerably reduced in size or even rudimentary.

Recule 27 octobre 1987. Accepté le 9 mars 1988.

\section{REFERENCES}

Bos L., 1957. Witches' broom phenomena, a patho-morphological study. Meded. Landbouwhogesch. Wageningen, 57 (1), 79 p.

Bos L., 1978. Symptoms of virus diseases in plants. 3 rd ed. Agric. Publis. Doc. Center, Wageningen, The Netherlands.

Cousin M. T., Abadie M. C., 1983. Remote action of MLOs on different cells of the anther pollen sacs. Proc. Int. Symp. on Patho. Mycopl., Bordeaux, July 8-11, 1983, p. 14.

Cousin M. T., Darpoux H., Faivre-Amiot A., Staron T., 1970. Sur la présence de micro-organismes de type mycoplasme dans le parenchyme cortical de féveroles présentant des symptomes de virescence. C. R. Acad. Sci. Paris, 271, 1182-1184.

Dafalla G. A., Cousin M. T., 1986. MLOs associated with some plant diseases in the Sudan : histochemical and ultrastructural studies. Proc. of 6th Int. Cong. IOM, Birmingham, Alabama, August 26-31.

Esau K., 1965. Plant Anatomy. 2nd ed., Wiley New York. 376 p.

Hussein M. M., 1976. Annu. Rep. Hudeiba Research Station. Botany Plant Pathol., 11-13.
Hussein M. M., 1978. Annu. Rep. Hudeiba Research Station. Botany Plant Pathol., 9-10.

Hussein M. M., 1979. Recent research on certain broadbeans (Vicia faba) diseases in the Sudan. Fabis, 1, 25.

Hussein M. M., Freigoun S. O., 1978. Diseases of broad beans (Vicia $f a b a)$ in the Sudan. In Food legume Improvement and development (G. G. Hawtin \& G. J. Chancellor eds). pp. 109-111, ICARDA/IDRC.

Icarda, 1984. Field guide of faba bean diseases in the Nile Valley. ICARDA, Aleppo. Syria.

Jones P., Cockrain A. J., Freigoun S. O., 1984. Association of a mycoplasma-like organism with broad bean phyllody in the Sudan. Plant Pathol., 33, 599-602.

Nour M. A., 1962. Witches' broom and phyllody in some plants in Khartoum province, Sudan. FAO Plant Prot. Bull., 10, 49-56. 